\title{
IMPACT OF CHANGES IN LAND USE AND CLIMATE ON THE RUNOFF BASED ON SWAT MODEL IN DAWEN RIVER BASIN, CHINA
}

\author{
ZHAO, Q. ${ }^{*}$-GAO, Q. - ZOU, C. H. - YAO, T. - LI, X. M. \\ School of Water Conservancy and Environment, University of Jinan \\ 336 Nanxinzhuang West Road, Jinan 250022, Shandong Province, China \\ (phone: +86-135-8910-8827) \\ *Corresponding author \\ e-mail: stu_zhaoq@ujn.edu.cn; phone: +86-135-8910-8827 \\ (Received $8^{\text {th }}$ Oct 2018; accepted $25^{\text {th }}$ Jan 2019)
}

\begin{abstract}
A distributed hydrological model (SWAT), which is widely used both domestically and internationally, was selected to quantitatively analyze the impact of land use and climate change on runoff in this paper in Dawen River Basin, China. The calibration and validation results obtained at Daicunba and Laiwu hydrological stations yield $\mathrm{R}^{2}$ values of 0.83 and 0.80 and 0.73 and 0.69 and the Ens values of 0.79 and 0.76 and 0.71 and 0.72 , respectively. Taking $1980-1990$ as the reference period, the annual runoff increased by 288 million $\mathrm{m}^{3}$, which was caused by changes in the land use of basin from 1991 to 2004, whereas the annual runoff decreased by 132 million $\mathrm{m}^{3}$ due to climate change. Land use changed from 2005 to 2015, which resulted in an increase in annual runoff of 13 million $\mathrm{m}^{3}$, and annual changes in climate caused a decrease in annual runoff of 61 million $\mathrm{m}^{3}$. An extreme land use scenario simulation analysis shows that, compared to the current land use simulation in 2000, the runoff of cultivated land scenarios and forest land scenarios was reduced by $38.3 \%$ and $19.8 \%$, respectively, and the runoff of grassland scenarios increased by $4.3 \%$. Climate change simulation analysis revealed that there was a positive correlation between runoff changes and precipitation changes in the river basin. The annual total runoff in the basin decreases with rising temperatures and decreases with decreasing temperatures, which showed that the impact of precipitation variability was stronger than that of change in air temperature.

Keywords: SWAT model; arbitrary scenario method; calibration and validation; runoff simulation
\end{abstract}

\section{Introduction}

Climate and land use are two important factors that influence the hydrological responses of a river. Climate variability can impact flow routing time, peak-flows and volume by affecting the amount and distribution of regional precipitation and temperature (Sahoo et al., 2018; Kalogeropoulos and Chalkias, 2013; Zuo et al., 2015a), whereas land-use changes can cause changes in baseflow, annual mean discharge, and flood frequency and severity (Lin et al., 2015; Anand et al., 2018; Memarian et al., 2014). In the context of climate change, drastic human activities have a great influence on watershed hydrology. Among these activities, land-use change is the most direct manifestation of human impact (Zou et al., 2018; Zeng et al., 2015). The impact of climate change on hydrology has become more and more serious in recent years, including quantity, quality, spatial and temporal distribution of water resources, and the degree of development and utilization of water resources. The impact of climate change on water resources has been the focus of a significant amount of current research (Sunde et al., 2018). The distributed hydrological model not only considers spacial heterogeneity but also has the advantage of portraying hydrological and physical processes (Uniyal et al., 2015; Zhang et al., 2018). In recent years, distributed hydrological models have been widely used to evaluate the hydrological effects of 
climate and land use changes. In many distributed hydrological models, the SWAT (Soil and Water Assessment Tool) model has been widely used in the simulation of basin water balance, long-term surface runoff and daily average runoff (Gyamfi et al., 2016). A large number of domestic studies have adopted models to simulate the effects of climate and land-use changes on the hydrological cycle of a river basin; in particular, these models have provided a basis for large-scale complex basin applications (e.g., the Haihe River Basin (Zhang and Chen, 2009), Yellow River Basin (Wang and Zheng, 2014), and Huaihe River Basin (Yang and Chen, 2017).

International research on climate change in the hydrological field began in the 1970s (Bull and Schick, 1979; Ruddiman et al., 1977; Lettenmaier and Burges, 1978), and studies on the impact of climate change on the water cycle began in the late 1980s in China (Wu et al., 2016; Lin et al., 2015; Zeng et al., 2013; Zhang and Yang, 2014). Based on global meteorological data from 1900 to 1998 and using RS and GIS technologies, Sanjay K. Jain conducted a simulation study on the effects of landuse/cover changes on the process of runoff and sediment production in the Satluj Watershed in the Himalayas (Jain et al., 2010). Prokop found that land-use change was an important factor of hydrological changes in the Himalayas from 1930 to 2010 (Prokop and Sarkar, 2012). Wei Chao quantitatively studied the dynamic change of land use in Taian based on RS technology (Wei et al., 2016). In this paper, the SWAT model is used to simulate runoff in Dawen River Basin. Through the simulation of watershed runoff in a changing environment, the tendency and rules of runoff under the background of climate change and land use are discussed, and the impacts of climate change and land use change on water resources in the river basin can be assessed. The results of the research provide effective means for the simulation, evaluation and analysis of water resources in the basin and the optimal allocation of water resources, which is of great significance for regional economic development and sustainable development.

\section{Materials and methods}

\section{Study area}

The Dawen River is located between $35^{\circ} 37^{\prime} 30^{\prime \prime}-36^{\circ} 32^{\prime} 30^{\prime \prime} \mathrm{N}$ and $116^{\circ} 11^{\prime} 15^{\prime \prime}-$ $118^{\circ} 0^{\prime} 0^{\prime \prime} \mathrm{E}$ in Shandong Province, China. The Dawen River flows from east to west and passes along Laiwu, Taian, Pingyin, and Wuyuan. The northern part of Dawen River Basin is mainly constrained by the Taishan Mountain Range and the Xiaoqing River; the eastern part is bounded by Lushan; the south is bordered by Mengshan, Yumai and Huaihe River basins; and the west is bordered by the Yellow River Basin. The east-west distance of the Dawen River Basin is approximately $176.6 \mathrm{~km}$; the north-south distance is approximately $102 \mathrm{~km}$; and the basin area is approximately $8726 \mathrm{~km}^{2}$ (Fig. 1).

\section{The SWAT hydrologic model}

The SWAT model is a basin-scale model that was developed by the Agricultural Research Service (ARS) of the United States Department of Agriculture (USDA). It is mainly used for the simulation of water quantity and quality of surface water and groundwater (Kiniry et al., 2005). This model has been widely used in different regions around the world and mainly used for the direct evaluation of the effects of human 
activities, climate variability or other factors related to large-scale precipitation (Wang et al., 2015).

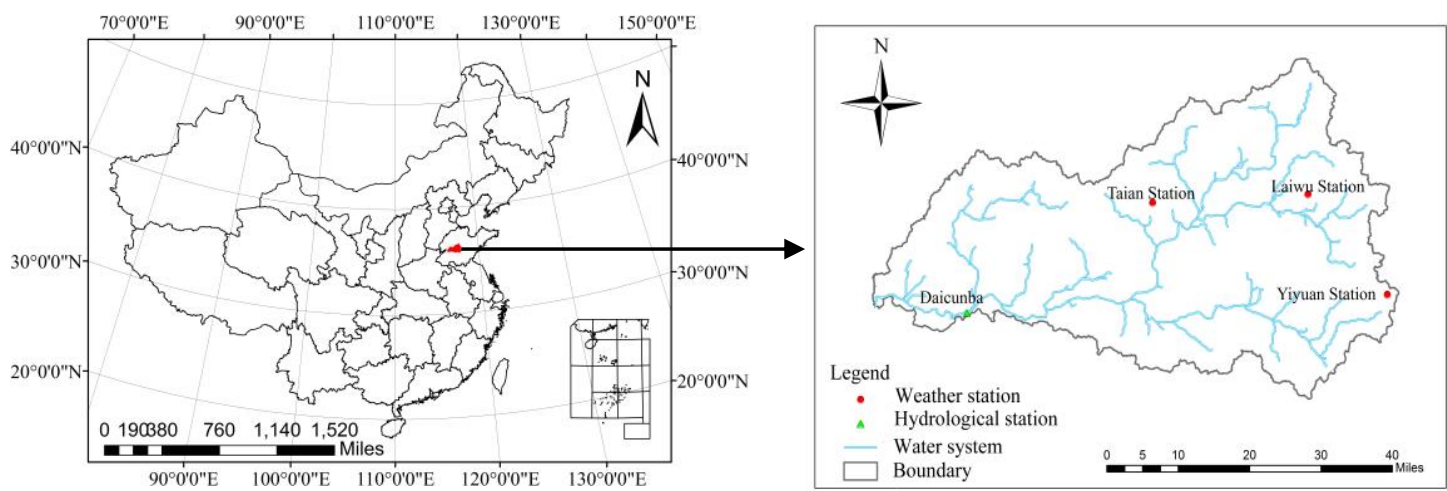

Figure 1. Dawen River Basin location map

The SWAT model partitions a watershed into sub-basins connected by a stream network and further delineates hydrologic response units (HRUs). By using data such as precipitation, soil properties, topography, land cover, and management, the surface runoff generated from each HRU can be calculated in each sub-watershed. The hydrologic cycle, as simulated by SWAT, is based on the water balance equation (Eq. 1), and the simulated processes include vadose zone processes and groundwater flow (Zhang et al., 2017).

$$
S W_{t}=S W_{o}+\sum_{i=1}^{t}\left(R_{d a y}-Q_{\text {surf }}-E_{a}-W_{\text {seep }}-Q_{g W}\right)_{i}
$$

where $\mathrm{SW}_{\mathrm{t}}$ is the final soil water content, $\mathrm{SW}_{0}$ is the initial soil water content, $\mathrm{t}$ (days) is the time, $R_{\text {day }}$ is the precipitation on day $i, Q_{\text {surf }}$ is the surface runoff on day $i, E_{a}$ is the evapotranspiration on day $\mathrm{i}, \mathrm{W}_{\text {seep }}$ is the amount of water entering the vadose zone from the soil profile on day $\mathrm{i}$ (soil interflow), and $\mathrm{Q}_{\mathrm{gw}}$ is the amount of return flow on day $\mathrm{i}$.

\section{The hydrologic model of the Dawen River Basin}

\section{SWAT model and database establishment}

The topographic, soil, land use and hydro-meteorological data were collected or generated as follows (Table 1). The 90*90 DEM downloaded data is geometrically corrected by using a binomial formula. The error must be less than 0.5 pixel units to meet the requirements of the model river network division and sub-basin extraction. The soil data were sourced from the soil database of the Harmonized World Soil Database (HWSD) and the HWSD by using the USDA standard. The soil data was corrected and interpreted by ENVI 5.1. The land use map obtained by processing the classification is converted into a land use type map in a format supported by the SWAT model, get the land use map of the study area in 1985 and 2000 and 2015 (Fig. 2). This study used the weather observation data of three traditional meteorological stations from 1980 to 2015 (the Taian, Yiyuan and Laiwu stations). 


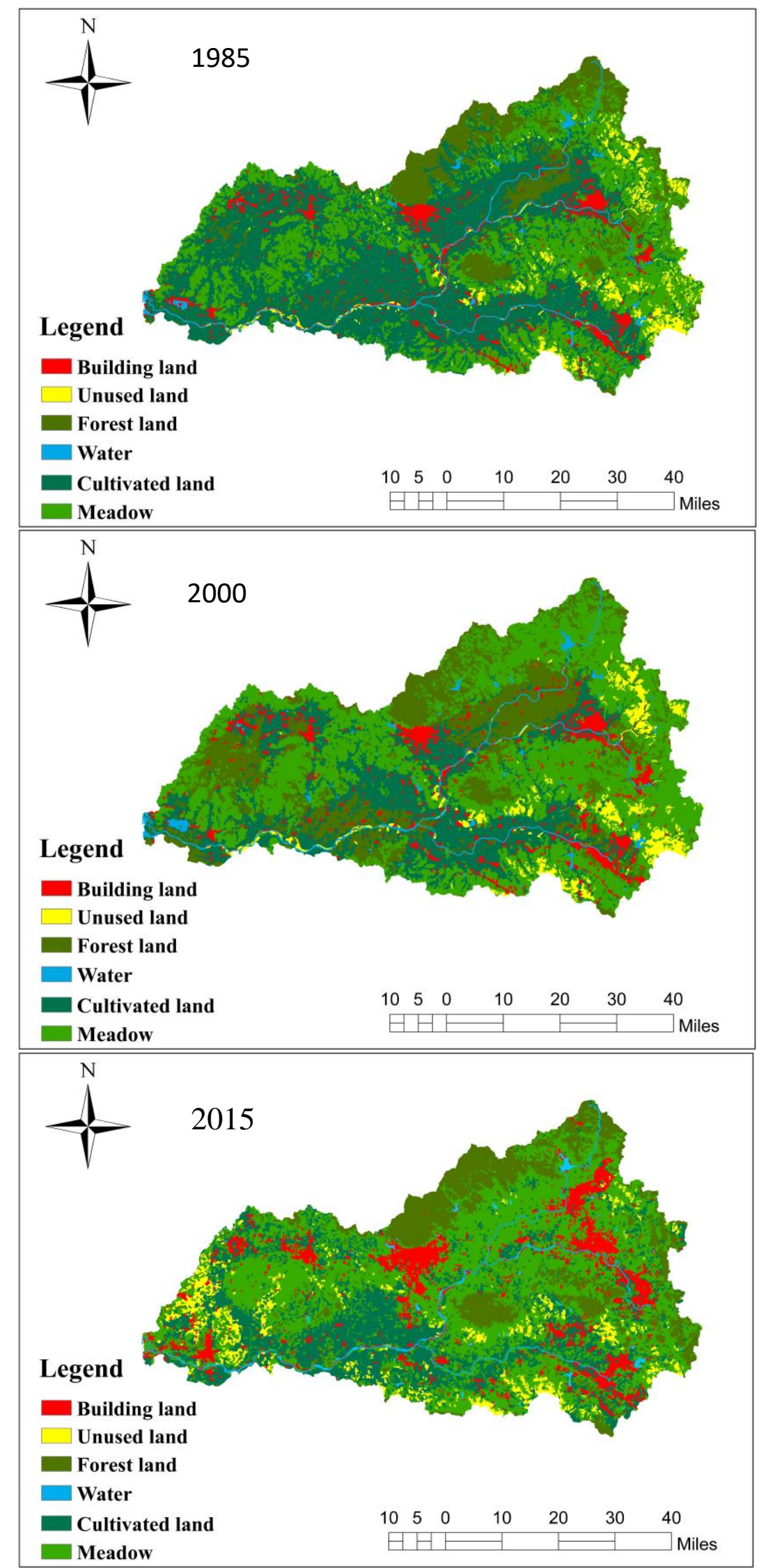

Figure 2. Land use of the Dawen River Valley in 1985, 2000 and 2015 
Table 1. Data sources and basic information

\begin{tabular}{c|c|c|c}
\hline Data & Accuracy & Formatting & Source \\
\hline DEM & $90 \mathrm{~m} \times 90 \mathrm{~m}$ & GRID & Geospatial Data Cloud \\
\hline Land Use Map in 2000 & $1 \mathrm{~km} \times 1 \mathrm{~km}$ & GRID & $\begin{array}{c}\text { Chinese Research Academy of } \\
\text { Environmental Sciences }\end{array}$ \\
\hline Soil type map & $1: 1000000$ & Shapefile Feature Class & Harmonized World Soil Database \\
\hline Meteorological data & Day & txt & Weather Data Sharing Network \\
\hline Hydrological data & Year, Month & txt & $\begin{array}{c}\text { Taian and Laiwu City } \\
\text { Hydrographic Bureau }\end{array}$ \\
\hline
\end{tabular}

\section{SWAT calibration and validation}

Based on the land use data and meteorological data in 2000 and the meteorological data from 1980 to 2015, the global sensitivity analysis module in SWAT-CUP was used to analyze the sensitivity of the parameters. The value of $\mathrm{T}$ provides the degree of sensitivity; the greater the absolute value is, the more sensitive it is. The $\mathrm{P}$ value indicates that the closer the significance value of sensitivity is to 0 , the more significant it is. Based on the measured data of the hydrological station, the sensitivity analysis of the parameters was performed, and parameters with strong sensitivity were selected to adjust the parameters. By using the official SWAT-CUP software, the parameters were adjusted (Khalid et al., 2018; Zhang et al., 2013). The SUFI-2 algorithm was used to determine the optimal value of the parameters by iteration (Zhang et al., 2013), and the best values of the parameters were introduced to the model through the internal tuning parameters of SWAT modelfor simulation verification. In this paper, the effective evaluation method defined by Karuse (Krause et al., 2005) is used to applicability of the simulated value of the SWAT model in Dawen River Basin was evaluated by using two indicators of correlation coefficient $\left(\mathrm{R}^{2}\right)$ and Nash-Sutcliffe efficiency coefficient (Ens). Scenarios were established to quantitatively analyze the impact of both of these indicators on river basin runoff and to separately analyze the impact of single land use type and different climate change scenarios on the runoff of the river basin. This provided an important scientific basis for water resource management and land-use planning under the influence of climate change and human activities. Relevant studies have suggested that simulations have significant effects when $\mathrm{R}^{2}>0.6$ and Ens $>0.5$ (Zuo et al., 2015b; Lotz et al., 2017).

\section{Scenario development and model analysis}

After verifying the accuracy of the model simulations, the response of the Dawen River basin to land use and climate change was analyzed by establishing five scenarios. The specific settings of these scenarios were presented in Table 2. In the simulation process, the parameters of the vegetation module and the soil hydraulic parameters were changed accordingly: Scenario 1 was used as the base period and compared to scenarios 4 and 5 to obtain the impact of both land use and climate change on production flows. Scenarios 2 and 3 were compared with scenario 1, and the impact of climate change on production flow was obtained. Then, scenarios 4 and 5 were compared with scenarios 2 and 3 , respectively, to obtain the impact of land-use change on production flow during the corresponding period. Finally, the impact of land use and climate change at different periods on the runoff of the entire river basin were quantitatively analyzed. 
Table 2. Model simulation scenario settings

\begin{tabular}{c|c|c}
\hline Scenarios & Land use & Climate data \\
\hline 1 & 1985 & $1980-1990$ \\
2 & 1985 & $1991-2004$ \\
3 & 1985 & $2005-2015$ \\
4 & 2000 & $1991-2004$ \\
5 & 2015 & $2005-2015$ \\
\hline
\end{tabular}

Based on the land use data in 2000, all of the land use types in the basin were set to farmland, forest land and grassland scenarios, and the corresponding soil hydrological parameters and vegetation module parameters were changed. The annual runoff under different land use scenarios was simulated from 2000 to 2015.

Based on a hypothetical climate plan (Yao et al., 2017), land use in 2000 and the possible scope of climate change, the values of the precipitation and temperature changes were obtained by using any scenario approach, and under the conditions of constant temperature and precipitation, the temperature increased by $1{ }^{\circ} \mathrm{C}$ and $2{ }^{\circ} \mathrm{C}$, and decreased by $1{ }^{\circ} \mathrm{C}$ and $2{ }^{\circ} \mathrm{C}$, respectively, the precipitation changes increased by $10 \%$ and $20 \%$ and decreased by $10 \%$ and $20 \%$, respectively. 25 climate change scenarios were established. The response of runoff to climate variability was simulated through different climate variability schemes. The annual change in runoff $b$ is solved as follows (Eq. 2):

$$
b=\left(y_{i}-y_{0}\right) / y_{0} \times 100 \%
$$

where $y_{i}$ is the average annual runoff under the $i$ climate scenario $\left(\mathrm{m}^{3} / \mathrm{s}\right)$; and $\mathrm{y}_{0}$ is the annual average runoff under a real scenario $\left(\mathrm{m}^{3} / \mathrm{s}\right)$.

\section{Results and analysis}

\section{Correction and verification results}

According to the natural river network and topography of the basin, the study area was divided into 35 sub-basins, as shown in Figure 3. To obtain a reasonable resolution to assess soil properties, land uses, and management practices, the threshold values of land use, soil type and slope were chosen as $10 \%, 15 \%$ and $10 \%$, respectively. These sub-basins were then further divided into 326 HRUs.

Through analysis, the first six sensitivity parameters were selected to adjust the parameters (Table 3). At the calibration period (Table 4; Figs. 4, 5 and 6), the simulated peak values in the flood season were lower than the measured values in 1999 and 2002, and higher than the measured values in 2000, 2005, and 2007; the $\mathrm{R}^{2}$ and Ens values in Daicunba were 0.83 and 0.79 , respectively. The simulated peak values in the flood season were lower than the measured values in 1985 and 1991, and higher than the measured values in 1982, 1987, 1988, and 1992; the $\mathrm{R}^{2}$ and Ens values in Laiwu station were 0.73 and 0.71 , respectively. The runoff simulation values of the two stations during the correction period have high precision. 


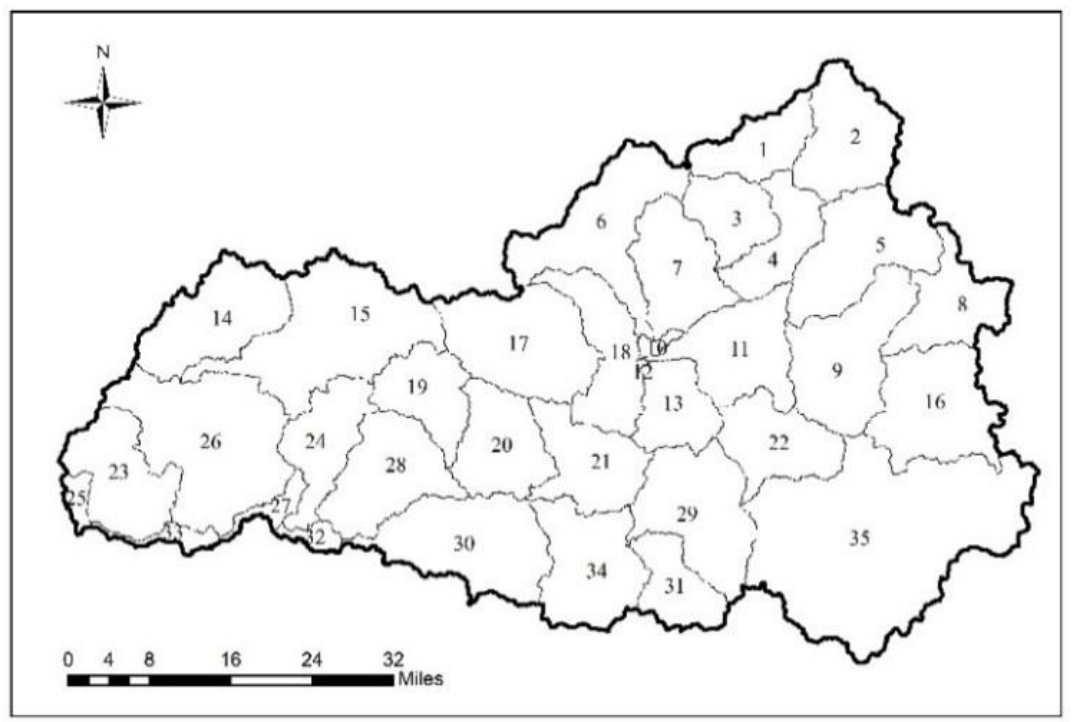

Figure 3. Sub-basins in the Dawen River Basin delineated by the SWAT

Table 3. Dawen River Basin runoff sensitivity parameters

\begin{tabular}{c|c|c|c|c|c|c}
\hline $\begin{array}{c}\text { Parameter } \\
\text { name }\end{array}$ & Variable name & Rank & T value & P value & Ranges & $\begin{array}{c}\text { The most } \\
\text { suitable value }\end{array}$ \\
\hline CN2 & Curve number & 1 & -18.133 & 0 & $0-15$ & 12.1687 \\
\hline ALPHA_BF & Base-flow recession constant & 2 & -2.578 & 0.012 & $0-1$ & 0.5364 \\
\hline SOL_K & Saturated hydraulic conductivity & 3 & -2.519 & 0.013 & $0-2.0$ & 0.6696 \\
\hline SOL_AWC & Available water capacity of the soil layer & 4 & -3.09 & 0.02 & $0.5-1.4$ & 0.6765 \\
\hline ESCO & $\begin{array}{c}\text { Soil evaporation compensation } \\
\text { coefficient }\end{array}$ & 5 & 1.8 & 0.08 & $0.3-0.9$ & 0.5713 \\
\hline GWQMN & $\begin{array}{c}\text { Threshold depth of water in the shallow } \\
\text { aquifer required for return flow to occur }\end{array}$ & 6 & -1.463 & 0.147 & $0-5000$ & 1763.47 \\
\hline
\end{tabular}

Table 4. Dawen River Basin monthly runoff simulation correction and verification

\begin{tabular}{c|c|c|c}
\hline Period & Site & $\mathbf{R}^{2}$ & Ens \\
\hline \multirow{2}{*}{ Regular rate } & Daicunba & 0.83 & 0.79 \\
& Laiwu Station & 0.73 & 0.71 \\
\hline \multirow{2}{*}{ Verification period } & Daicunba & 0.80 & 0.76 \\
& Laiwu Station & 0.69 & 0.72
\end{tabular}

During the verification period (Table 4; Figs. 4, 5 and 6), the simulated peak value in the flood season was lower than the measured value in 2013, and higher than the measured values in 2009, 2012 and 2015; the $\mathrm{R}^{2}$ and Ens values in Daicunba were 0.80 and 0.76, respectively. The simulated peak values in the flood season were lower than the measured values in 1999, and higher than the measured values in 1996 and 2001; the $\mathrm{R}^{2}$ and Ens values in Laiwu Station were 0.69 and 0.72, respectively. The accuracy of the runoff simulation values at the two stations during the verification period is thus adequate. 


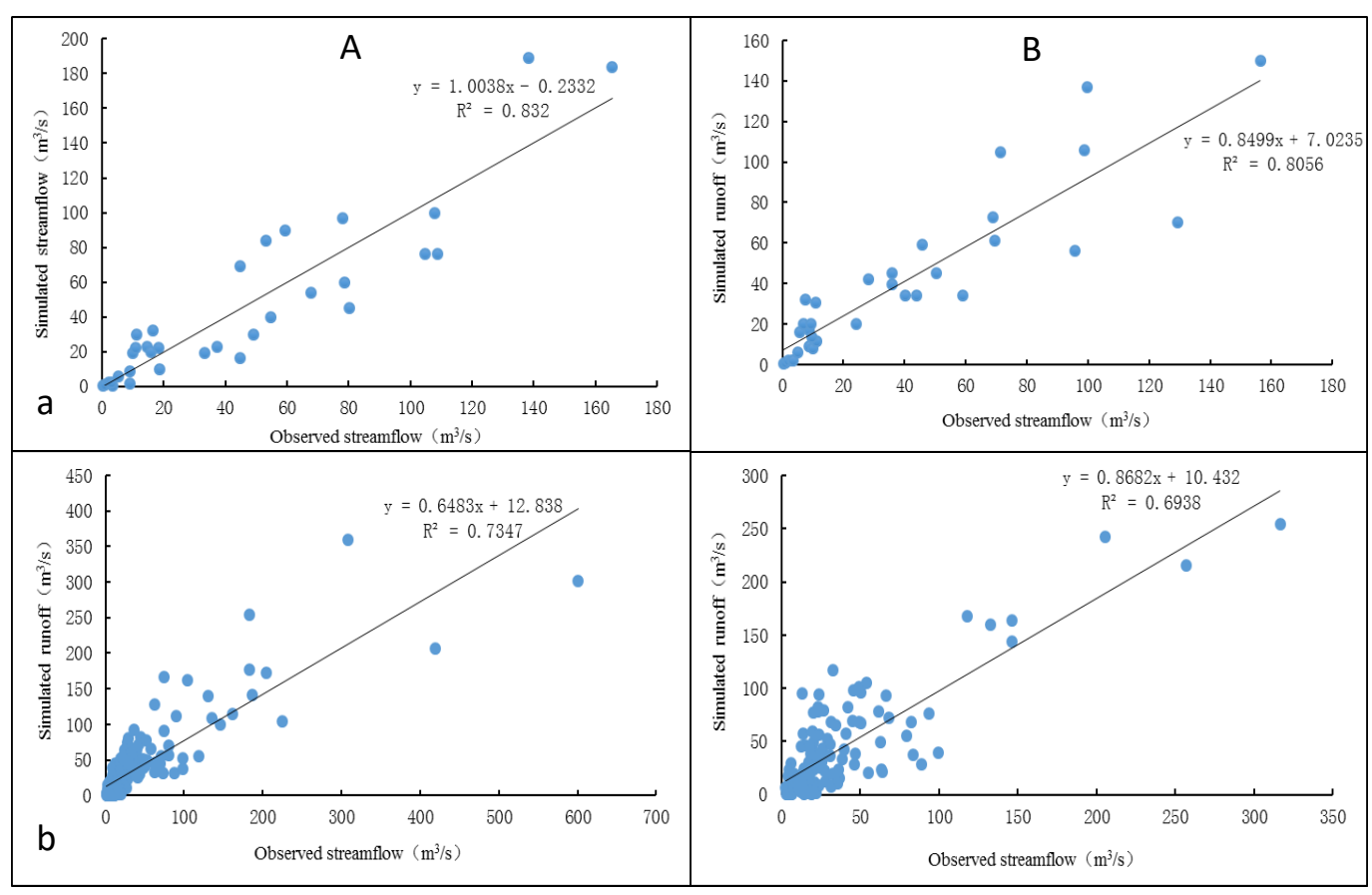

Figure 4. Correlation between simulated and measured values of monthly runoff in the hydrological stations A: Rate period; B: Validated period; a) Daicunba; and b) Laiwu station

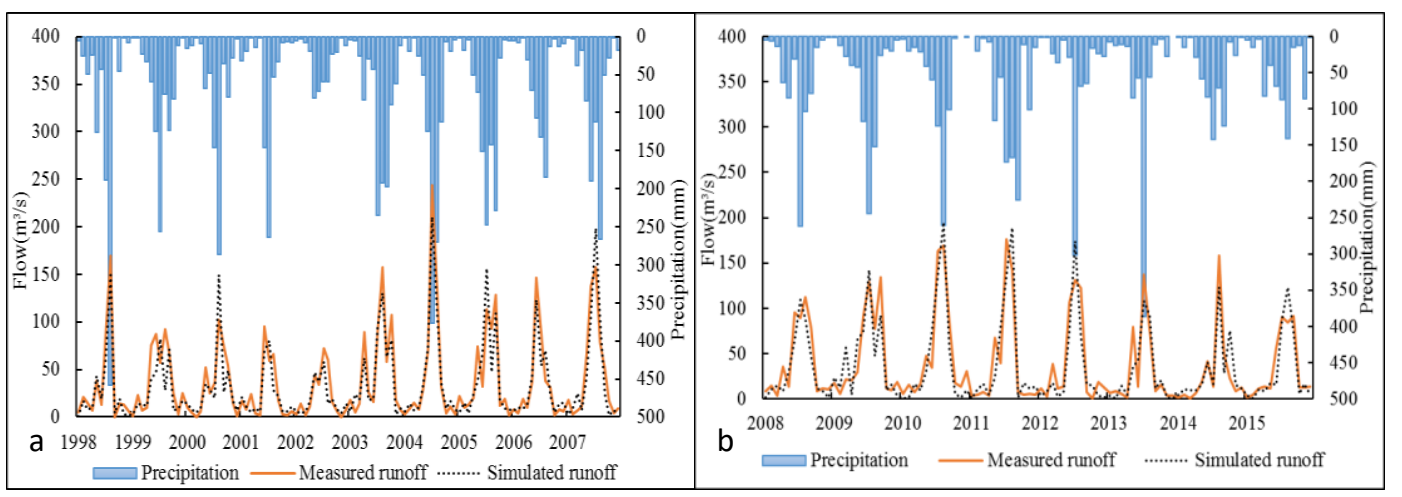

Figure 5. Daicunba hydrological station monthly runoff simulation and actual measurement comparison chart. a: Rate period; $b$ : Validated period

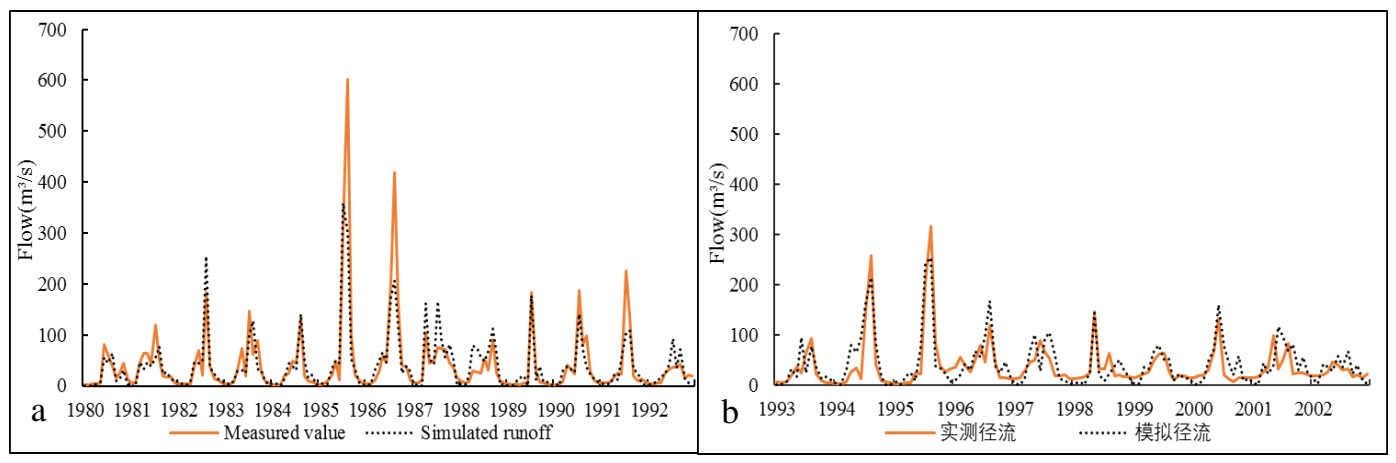

Figure 6. Laiwu hydrological station monthly runoff simulation and actual measurement comparison chart. a: Rate period; $b$ : Validated period 
For the determination and verification of monthly runoff, the deterministics coefficient of the measured and simulated values of runoff are $\mathrm{R}^{2}>0.6$ and Ens $>0.6$. This shows that the measured values of runoff are in good agreement with the simulated values and that the SWAT model has good applicability in the study area.

\section{Simulation scenarios}

\section{Responses of streamflow to different land use scenarios}

To understand the impact of land-use changes on streamflow in this basin, the calibrated SWAT model was run under scenarios S1 S4 and S5. The percentages of land-use change rates and the changes in land use area in kilometers under these three scenarios are shown in Figure 7 and Table 5. In scenario S1, the status of land use in Dawen River was mainly meadow (27.69\%), forest land (19.07\%), cultivated land $(28.18 \%)$, and building land $(12.17 \%)$. Compared to scenario S1, the area of forest land increased by $23.66 \%$, the area of building land increased by $11.08 \%$, and the area of cultivated land and unused land decreased by $24.38 \%$ and $6.93 \%$, respectively, in scenario S4. Compared to scenario S4, the area of forest land decreased by $27.66 \%$ and that of unused land decreased by $3.57 \%$, the area of the meadow increased by $10.64 \%$, and the area of building land increased by $17.27 \%$ in scenario S5. From 1985 to 2015 , the meadow area increased by $17.85 \%$ and the cultivated land area decreased by $18.3 \%$. The water area did not change much.

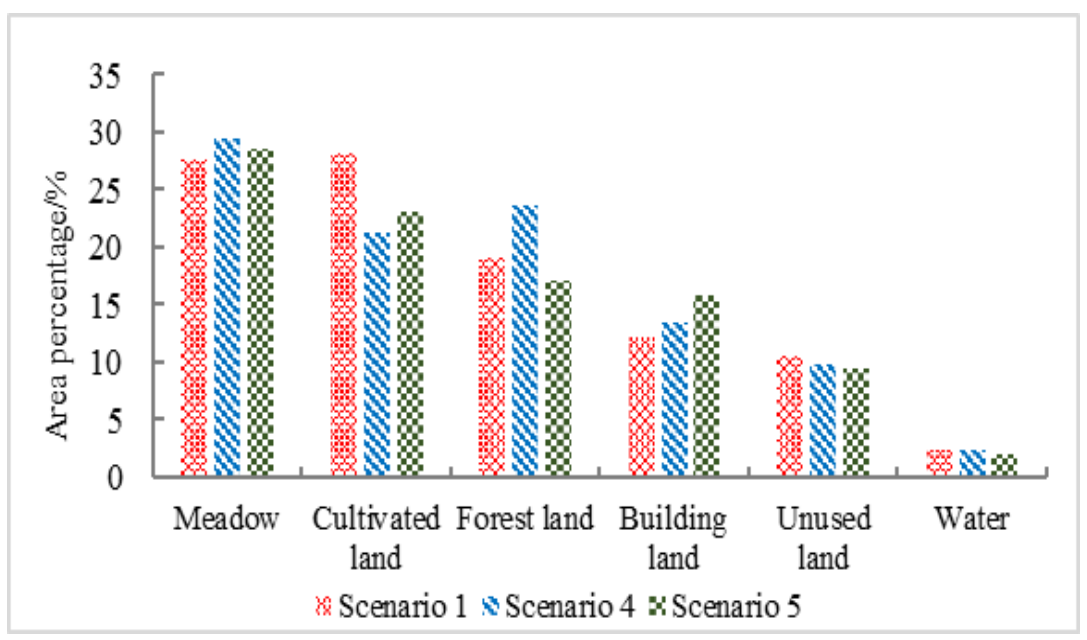

Figure 7. Percentages of land uses under three scenarios

Table 5. Proportion of land use in the Dawen River Basin in 1985, 2000 and 2015

\begin{tabular}{c|c|c|c|c|c|c}
\hline Year & $\begin{array}{c}\text { Meadow } \\
(\boldsymbol{\%})\end{array}$ & $\begin{array}{c}\text { Cultivated } \\
\text { land (\%) }\end{array}$ & $\begin{array}{c}\text { Forest land } \\
(\boldsymbol{\%})\end{array}$ & $\begin{array}{c}\text { Building land } \\
(\boldsymbol{\%})\end{array}$ & $\begin{array}{c}\text { Unused land } \\
(\boldsymbol{\%})\end{array}$ & $\begin{array}{c}\text { Water } \\
(\boldsymbol{\%})\end{array}$ \\
\hline 1985 & 27.69 & 28.18 & 19.07 & 12.17 & 10.56 & 2.33 \\
2000 & 29.49 & 21.31 & 23.59 & 13.51 & 9.83 & 2.27 \\
2015 & 28.51 & 23.02 & 17.06 & 15.85 & 9.48 & 1.96 \\
\hline
\end{tabular}

Based on the situational settings, a quantitative study was conducted on the runoff response to land use and climate change in Dawen River Basin (Table 6). The results 
show that the average annual runoff values in scenarios $1,2,3,4$ and 5 are 9.21, 7.89, $7.28,8.17$, and 7.41 million $\mathrm{m}^{3}$, respectively. Scenarios 2 and 3 are compared to Scenario 1. Climate change caused an annual average runoff reduction of 1.32 and 0.61 million $\mathrm{m}^{3}$. The comparison between Scenario 2 and Scenario 4 results in an increase of 28 million $\mathrm{m}^{3}$ in average annual runoff due to the change in land use. The comparison between Scenario 3 and Scenario 5 results in an increase of 13 million $\mathrm{m}^{3}$ in average annual runoff due to land use change.

Table 6. Simulation results of land use and climate change impact on runoff in the Dawen River Basin

\begin{tabular}{c|c|c|c|c|c}
\hline Scenario & $\begin{array}{c}\text { Annual } \\
\text { precipitation } \\
(\mathbf{m m})\end{array}$ & $\begin{array}{c}\text { Annual average } \\
\text { temperature } \\
\left({ }^{\circ} \mathbf{C}\right)\end{array}$ & $\begin{array}{c}\text { Average annual } \\
\text { flow }\left(\mathbf{1 0}^{\mathbf{9}} \mathbf{m}^{\mathbf{3}}\right)\end{array}$ & $\begin{array}{c}\text { Impact of land } \\
\text { use change on } \\
\text { runoff }\left(\mathbf{1 0}^{\mathbf{9}} \mathbf{m}^{\mathbf{3}}\right)\end{array}$ & $\begin{array}{c}\text { Impact of climate } \\
\text { change on runoff } \\
\left(\mathbf{1 0}^{\mathbf{3}} \mathbf{m}^{\mathbf{}}\right)\end{array}$ \\
\hline 1 & - & - & 9.21 & - & - \\
2 & & 13.4 & 7.89 & - & -1.32 \\
3 & 755.7 & & 7.28 & - & -0.61 \\
4 & - & - & 8.17 & 0.28 & - \\
5 & - & - & 7.41 & 0.13 & - \\
\hline
\end{tabular}

Annual average runoff changes under different extreme land use scenarios

The runoff variation under three different extreme scenarios was compared to simulated runoff under the land use scenario in 2000 (Fig. 8). The runoff in the cultivated land scenario decreased by $38.3 \%$, and the runoff decreased by $19.8 \%$ in the forest land scenario. However, the runoff increased by $4.3 \%$ in the grassland scenario. These results show that grassland can increase the runoff and water supply in the basin to conserve water resources. The increase in cultivated land will lead to a large reduction in runoff. Because cultivated land has the effect of inhibiting the increase of runoff, human activities have a greater impact on hydrology.

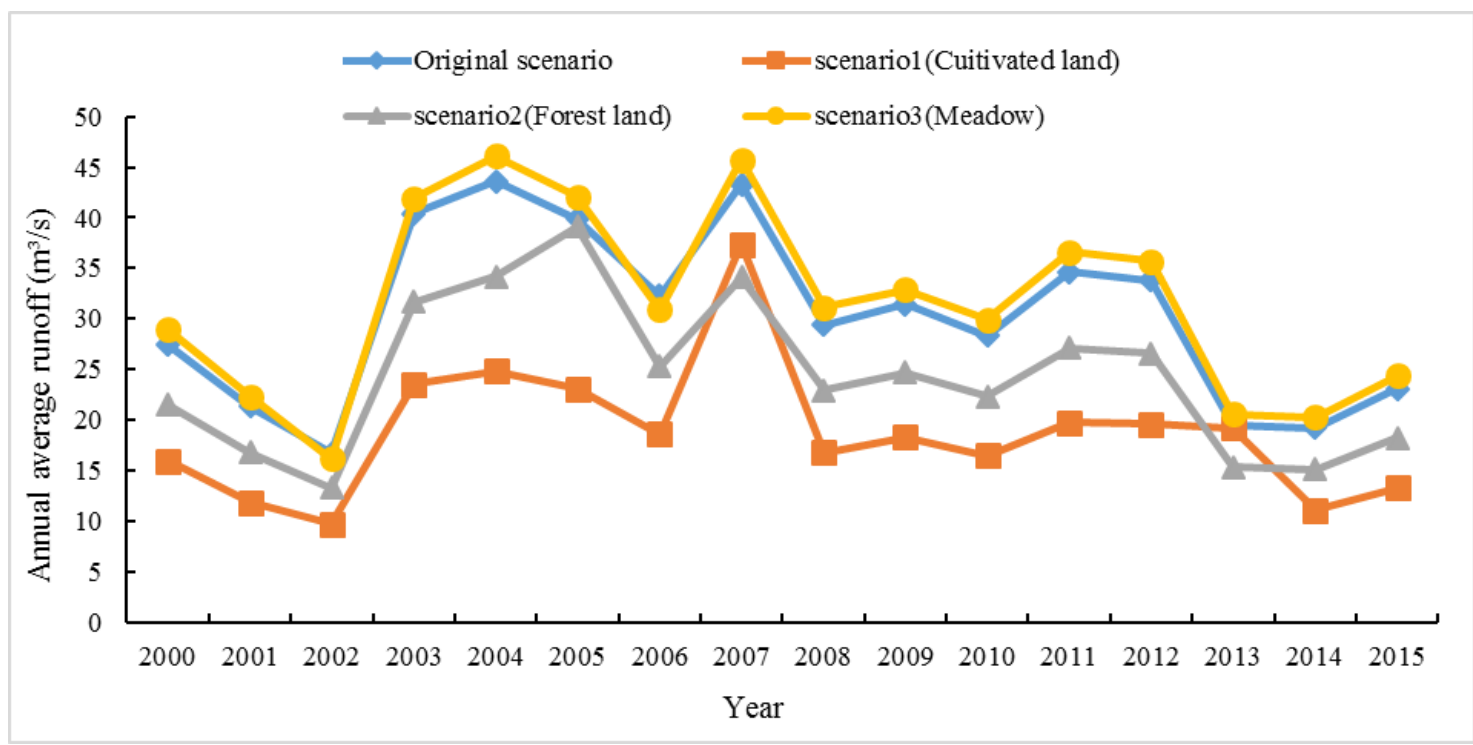

Figure 8. Simulated runoff changes in extreme land use scenarios 


\section{Influence of temperature and rainfall on average runoff in the basin}

It can be seen from the annual average temperature and precipitation cumulative anomaly curve in the Dawen River Basin (Fig. 9). From 1990 to 1995, the temperature accumulation anomaly curve showed a downward trend, which was a period of low temperature. From 1995 to 2009, the temperature accumulation anomaly curve showed an upward trend, which was a period of higher temperature. Then, the temperature accumulation anomaly curve began to rise after a short decline until 2015, and the overall situation was relatively stable. The average temperature over 26 years is approximately $13.4{ }^{\circ} \mathrm{C}$ and is growing at a speed of $0.47{ }^{\circ} \mathrm{C} / 10 \mathrm{a}$. The cumulative anomaly curve of precipitation in the Dawen River Basin from 1990 to 1998 showed a downward trend, which was a period of low rainfall. The cumulative anomaly curve of precipitation in 1998-2002 experienced a short stage of rising and falling, and the overall situation was relatively stable. From 2002 to 2015, the cumulative anomaly curve of precipitation showed an upward trend, which was a rainy period. According to this analysis, the average precipitation in Dawen River Basin during the past 26 years is $755.7 \mathrm{~mm}$, and the annual average precipitation has decreased overall. The reduction rate is approximately $54.9 \mathrm{~mm} / 10 \mathrm{a}$.
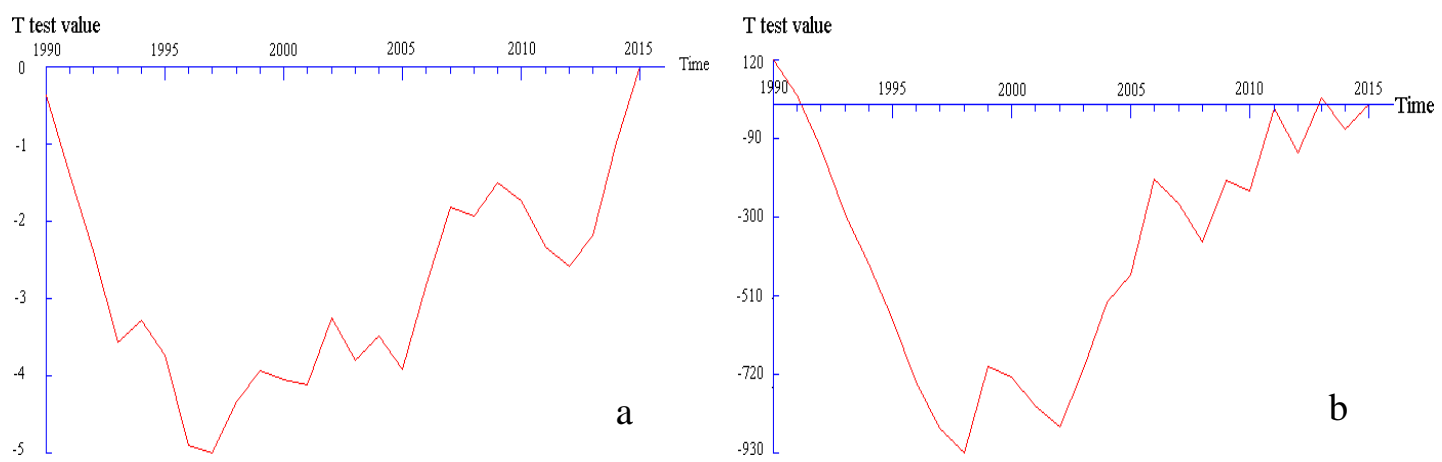

Figure 9. Cumulative anomaly curve. a: Temperature; $b$ : Precipitation

It can be seen from Figure 10 and Table 7 that the multi-year average runoff variation in Dawen River Basin is mainly related to rainfall and temperature in the basin. First, the annual total runoff of the basin decreases with increasing temperature and decreases with decreasing temperature. The annual runoff decreased by $4.1 \%$ when the temperature increased by every $1{ }^{\circ} \mathrm{C}$; the annual runoff decreased by approximately $3.0 \%$ when the temperature decreased every by $1{ }^{\circ} \mathrm{C}$. This indicates that temperature is one of the main sensitive factors affecting runoff in the basin. Second, there is a positive correlation between rainfall and annual runoff in the basin. The annual runoff of the basin increases with the increase in annual rainfall, and the increase in runoff is greater than the increase in rainfall. When the annual rainfall in the basin increases by every $10 \%$, the annual total runoff increases by approximately $18.3 \%$. The average annual runoff of the basin decreases with the decrease of precipitation, but its reduction of rainfall is smaller than its increase of rainfall. When the annual rainfall decreases by every $10 \%$, the annual average runoff decreases by $15.1 \%$. Precipitation is an important factor affecting runoff in the basin. Compared to the change of temperature, the annual runoff of the basin is more affected by rainfall. 
Table 7. Simulation results of different climate change scenarios

\begin{tabular}{|c|c|c|c|c|c|}
\hline $\begin{array}{l}\text { Precipitation change } \\
\text { Temperature changes }\end{array}$ & $-20 \%$ & $-10 \%$ & 0 & $+10 \%$ & $+20 \%$ \\
\hline T-2 & -29.7 & -18.2 & -3.3 & 11.2 & 33.1 \\
\hline $\mathrm{T}-1$ & -29.1 & -19.4 & -3.0 & 10.7 & 34.4 \\
\hline 0 & -27.1 & -15.1 & 0 & 18.3 & 30.7 \\
\hline $\mathrm{T}+1$ & -30.6 & -20.2 & -4.1 & 11.1 & 32.5 \\
\hline $\mathrm{T}+2$ & -30.3 & -21.5 & -4.7 & 12.2 & 31.8 \\
\hline
\end{tabular}

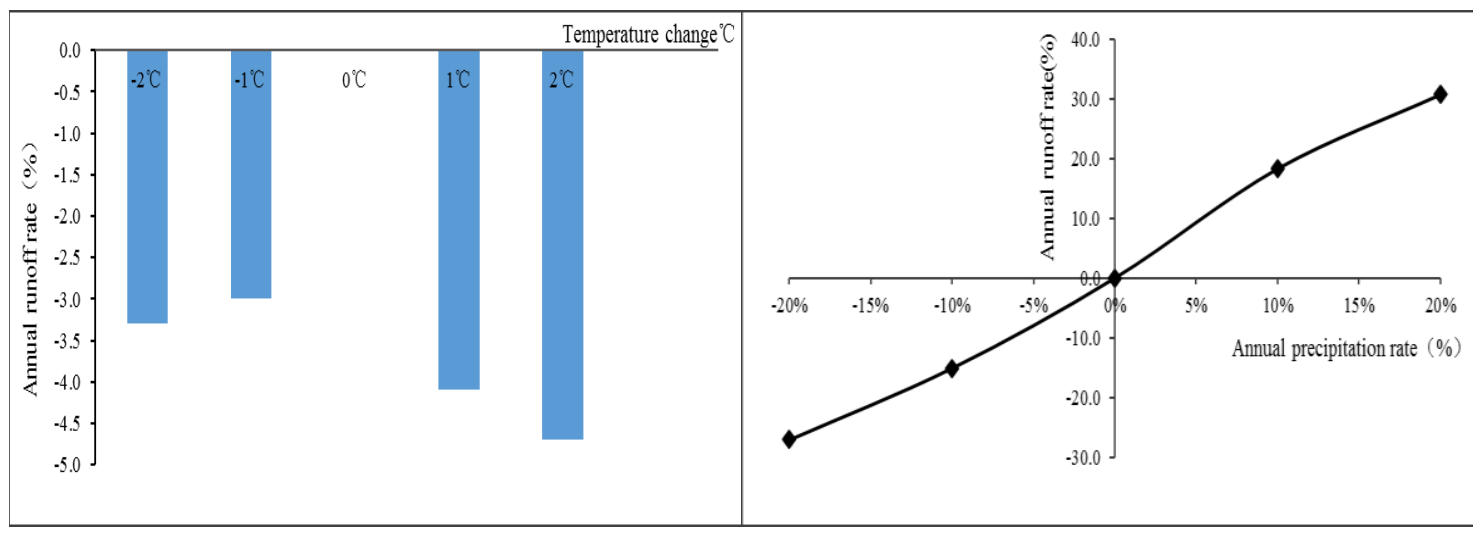

Figure 10. Annual runoff rate of the Dawen River Basin under changes in temperature and precipitation

\section{Conclusion}

In this paper, the distributed hydrological model (SWAT) is applied to quantitatively simulate the impact of land use and climate change on water production in Dawen River Basin through multi-site calibration and verification. The results are shown as follows:

(1) The calibration and validation at two hydrological stations showed that the $\mathrm{R}^{2}$ values were 0.83 and 0.80 and 0.73 and 0.69 , and the Ens values were 0.79 and 0.76 and 0.71 and 0.72 , respectively, which satisfied the SWAT model simulation accuracy evaluation criteria. Therefore, the SWAT model was suitable for this research basin. The parametric model can be applied directly to the actual situation in the basin.

(2) Land use and climate change in different periods have different effects on water yield in the basin. Scenarios 2 and 3 are compared to Scenario 1, indicating that climate change caused annual average runoff reductions of 1.32 and 0.61 billion $\mathrm{m}^{3}$, respectively. The comparison between Scenario 2 and Scenario 4 results in an increase of 28 million $\mathrm{m}^{3}$ in annual average runoff due to the change in land use. The comparison between Scenario 3 and 5 shows an increase of 13 million $\mathrm{m}^{3}$ in average annual runoff due to land-use change.

(3) The simulation results of different land use types showed that the runoff in cultivated land decreased by $38.3 \%$, the runoff in forest land decreased by $19.8 \%$, and the runoff in grassland increased by $4.3 \%$. Therefore, in the future watershed management process of Dawen River Basin, the type of land use will be adjusted to meet the water demand in the basin, increase the water output of the basin and ensure water use downstream of the basin. 
(4) By analyzing the rate of runoff change in the basin under various climate scenarios, the annual total runoff in the basin decreases with the increase of temperature, and decreases with the decrease of temperature. The annual runoff increased with the increase of annual rainfall and the increase of runoff was greater than the increase of rainfall. The annual average runoff of the basin decreased with the decrease of precipitation, but its degree of decrease of rainfall was smaller than its degree of increase of rainfall.

(5) Runoff is not only affected by changes in land use but also by climate change. If the change in runoff is mainly caused by land use, the water resources planning and management policy can still be formulated based on current hydrology and meteorological data; If the main factor causing the change in runoff is climate change, then it is necessary to focus on the impact of future climate change on hydrology and water resources, and the research can also provide a reference for water resources planning management.

Acknowledgements. We express our sincere appreciation to the anonymous reviewers for their constructive suggestions. The work was supported by the special program for the National Natural Science Foundation of China (41471160). The authors would also to thank the reviewers for their very valuable comments, which greatly improved the quality of the paper.

\section{REFERENCES}

[1] Anand, J., Gosain, A. K., Khosa, R. (2018): Prediction of land use changes based on Land Change Modeler and attribution of changes in the water balance of Ganga basin to land use change using the SWAT model. - The Science of the Total Environment 644: 503519.

[2] Bull, W. B., Schick, A. P. (1979): Impact of climatic change on an arid watershed: Nahal Yael, southern Israel. - Quaternary Research 11(2): 153-171.

[3] Gyamfi, C., Ndambuki, J. M., Salim, R. W. (2016): Application of SWAT model to the Olifants Basin: calibration, validation and uncertainty analysis. - Journal of Water Resource \& Protection 08(3): 397-410.

[4] Jain, S. K., Tyagi, J., Singh, V. (2010): Simulation of runoff and sediment yield for a Himalayan watershed using SWAT model. - Journal of Water Resource \& Protection 2(3): 267-281.

[5] Kalogeropoulos, K., Chalkias, C. (2013): Modelling the impacts of climate change on surface runoff in small Mediterranean catchments: empirical evidence from Greece. Water Environ. J. 27(4): 505-513.

[6] Khalid, K., Ali, M. F., Rahman, N. F. A., Othman, Z., Bachok, M. F. (2018): Calibration Assessment of the Distributed Hydrologic Model Using SWAT-CUP. - In: Yacob, N. N. et al. (eds.) Regional Conference on Science, Technology and Social Sciences (RCSTSS 2016). Springer, Singapore, pp.241-250.

[7] Kiniry, J. R., Williams, J. R., King, K. W. (2005): Soil and Water Assessment Tool theoretical documentation (Version 2005). - Computer Speech \& Language 24(2): 289306.

[8] Krause, P., Boyle, D. P., Bäse, F. (2005): Comparison of different efficiency criteria for hydrological model assessment. - Advances in Geosciences 5: 89-97.

[9] Lettenmaier, D. P., Burges, S. J. (1978): Climate change: detection and its impact on hydrologic design. - Water Resources Research 14(4): 679-687. 
[10] Lin, B., Chen, X., Yao, H., Chen, Y., Liu, M., Gao, L., James, A. (2015): Analyses of land use change impacts on catchment runoff using different time indicators based on SWAT model. - Ecol. Indic. 58: 55-63.

[11] Lin, T. P., Lin, Y. P., Lien, W. Y. (2015): Evaluating Impacts of climate and land use changes on streamflow using SWAT and land use models based CESM1-CAM5 Climate scenarios. - EGU General Assembly Conference.

[12] Lotz, T., Opp, C., He, X. (2018): Factors of runoff generation in the Dongting Lake basin based on a SWAT model and implications of recent land cover change. - Quatern. Int. 10(475): 54-62.

[13] Memarian, H., Balasundram, S. K., Abbaspour, K. C., Talib, J. B., Sung, C. T. B., Sood, A. M. (2014): SWAT-based hydrological modelling of tropical land-use scenarios. Hydrolog. Sci. J. 59(10): 1808-1829.

[14] Prokop, P., Sarkar, S. (2012): Natural and human impact on land use change of the Sikkimese-Bhutanese Himalayan Piedmont, India. - Quaestiones Geographicae 31(3): 63-75.

[15] Ruddiman, W. F., Sancetta, C. D., Mcintyre, A. (1977): Glacial/interglacial response rate of subpolar North Atlantic waters to climatic change: the record in oceanic sediments [and discussion]. - Philosophical Transactions of the Royal Society of London 280(972): 119-142.

[16] Sahoo, S., Dhar, A., Debsarkar, A., Kar, A. (2018): Impact of water demand on hydrological regime under climate and LULC change scenarios. - Environ. Earth. Sci. 77(9): 341.

[17] Sunde, M. G., He, H. S., Hubbart, J. A., Urban, M. A. (2018): An integrated modeling approach for estimat-ing hydrologic responses to future urbanization and climate changes in a mixed-use midwestern watershed. - J. Environ. Manage. 220: 149-162.

[18] Uniyal, B., Jha, M. K., Verma, A. K. (2015): Assessing climate change impact on water balance components of a river basin using SWAT model. - Water Resour. Manag. 29(13): 4767-4785.

[19] Wang, J., Zheng, Y. (2014): preliminary applicable analysis of SWAT model in the Three Rivers source area. - Meteorological \& Environmental Sciences 37(3): 102-107 (in Chinese).

[20] Wang, X. P., Qiao, F., Lei, K., Ren, G. J., Wang, X. L. (2015): Research on and Application of SWAT Model in China. - China Rural Water \& Hydropower 5: 109-113 (in Chinese).

[21] Wei, C., Jia, Y., Wu, H., Zhao, L., Zhang, S. (2016): Research on land use dynamic change of Tai'an based on RS. - Beijing Surveying and Mapping (06): 123-127 (in Chinese).

[22] Wu, Y., Liu, S., Yan, W., Xia, J., Xiang, W., Wang, K., Luo, Q., Fu, W., Yuan, W. (2016): Climate change and consequences on the water cycle in the humid Xiangjiang River Basin, China. - Stochastic Environmental Research \& Risk Assessment 30(1): 225235.

[23] Yang, M., Chen, X. (2017): Effects of climate change on extreme streamflow in flood season in the upper and middle basin of the Huaihe River by SWAT simulation. - Acta Ecologica Sinica 37(23): 8107-8116 (in Chinese).

[24] Yao, M., Chen, F., Zhao, S. (2017): Discussion on the impact of climate change on hydrology and water resources. - Theoretical Research in Urban Construction (14): 149 (in Chinese).

[25] Zeng, S., Zhang, L., Xia, J., Zhen, Y. (2013): Water cycle characteristic and its responses to climate change of the Yongding River Basin. - Journal of Basic Science \& Engineering 21(3): 501-511.

[26] Zeng, S., Zhan, C., Sun, F., Du, H., Wang, F. (2015): Effects of climate change and human activities on surface runoff in the Luan River Basin. - Adv. Meteorol. 6: 1-12. DOI: $10.1155 / 2015 / 740239$. 
[27] Zhang, L., Karthikeyan, R., Bai, Z., Srinivasan, R. (2017): Analysis of streamflow responses to climate variability and land use change in the Loess Plateau region of China. - Catena 154: 1-11.

[28] Zhang, L., Nan, Z., Yu, W., Zhao, Y., Xu, Y. (2018): Comparison of baseline period choices for separating climate and land use/land cover change impacts on watershed hydrology using distributed hydrological models. - Sci. Total. Environ. 622: 1016-1028.

[29] Zhang, X., Yang, S. (2014): Climatic and anthropogenic impacts on water discharge in the Yangze River over the last 56 years (1956-2011). - Resources and Environment in the Yangtze Basin 23(12): 1729-1739 (in Chinese).

[30] Zhang, Y., Chen, C., Yang, X., Yin, Y., Du, J. (2013): Application of SWAT model based sufi-2 algorithm to runoff simulation in Xiushui Basin. - Water Resources and Power (9): 24-28 (in Chinese).

[31] Zhang, Y., Chen, X. (2009): Extended water quality module of SWAT model and its application to Hai River Basin. - Resources Science 31(1): 94-100 (in Chinese).

[32] Zou, L., Xia, J., She, D. (2018): Analysis of impacts of climate change and human activities on hydrological drought: a case study in the Wei River Basin, China. - Water Resour. Manag. 32(4): 1421-1438.

[33] Zuo, D., Xu, Z., Yao, W., Jin, S., Xiao, P., Ran, D. (2015b): Assessing the effects of changes in land use and climate on runoff and sediment yields from a watershed in the Loess Plateau of China. - Sci. Total. Environ. 544: 238-250.

[34] Zuo, D., Xu, Z., Zhao, J., Abbaspour, K. C., Yang, H. (2015a): Response of runoff to climate change in the Wei River basin, China. - Hydrolog. Sci. J. 60(3): 508-522. 